\title{
Over hesperiaanse melancholie: Eugène Nielen Marais en de geschiedenis van een poëtische gemoedsgesteldheid
}

\author{
RUBEN VAN LUIJK \\ independent researcher \\ Reitdiepstraat 26 I \\ 3522 GJ Utrecht \\ Nederland \\ ruben@vanluijk.be
}

\section{On Hesperian Depression: Eugène Nielen Marais and the history of a poetical state of the soul}

\begin{abstract}
The article gives a brief 'idea history' of Hesperian melancholy a.k.a. Hesperian depression, the fleeting state of dejection that some humans and animals experience at dusk. The term was apparently coined by the South African poet and naturalist Eugène Marais (1871-1936), who noticed the phenomenon during his field observations of baboons. Marais' observations of primates were in the first place an attempt to shed more light on the evolutionary roots of the human psyche and its afflictions - not in the least his own. A personal focus seems probable in his notes on the use of euphoria-inducing substances among animals and humans, which are an evident reflection of his own morphine addiction; but also in his writings about Hesperian depression. During his lifetime, Marais only published about Hesperian depression twice, once in a very concise article in English, and once in more elaborate form in Afrikaans. The term 'Hesperian depression' only became more current when his manuscript on primate behaviour, The Soul of the Ape, was posthumously published in 1963. Since then, the term and its description sometimes appear in (popular) publications of paleobiologists and scholars of the evolution of human behaviour. In psychology and psychiatry, the term was introduced by the eminent American psychoanalyst William G. Niederlander, who presented it in a 1971 article in Journal of the American Psychoanalytic Association as an idea of his own. It is evident, however, that he took his cue from Marais, who thus was posthumously plagiarized.
\end{abstract}

Keywords: Hesperian depression; Hesperian melancholy; Eugène Nielen Marais; William G. Niederlander; baboons; South Africa; South African literature; (history of) evolutionary biology; (history of) psychology and psychiatry; plagiarism 
"Eddie Willers liep verder, zich afvragend waarom hij het altijd voelde op deze tijd van de dag, dat gevoel van vrees zonder reden. Nee, dacht hij, niet vrees, er is niets te vrezen; alleen een onmetelijke, diffuse bezorgdheid zonder oorsprong of doel. [...] Het is de schemering, dacht hij; ik haat de schemering" (Rand 2007: 3). Met deze woorden op de eerste bladzijde van haar monumentale roman Atlas Shrugged (1957) beschrijft de Amerikaanse schrijfster Ayn Rand een gevoel dat bijna iedereen van ons wel eens bekruipt op het moment dat de avond valt: een stemming van zwaarmoedigheid en verlatenheid die geen duidelijke oorzaak of doel lijkt te hebben. Net als de meeste lezers was Rand zich vermoedelijk niet bewust van het feit dat er een naam bestaat voor deze gemoedsgesteldheid: hesperiaanse melancholie, of ook wel: hesperiaanse depressie. Hesperiaanse melancholie is met stip de meest poëtische aandoening van de ziel die ik ken. Ondanks de onmiskenbare Antieke connotaties die de benaming met zich meedraagt, stamt ze niet uit de krochten van de Oudheid. Ze is integendeel bedacht in de twintigste eeuw, naar alle waarschijnlijkheid door de ZuidAfrikaanse dichter en amateurbioloog Eugène Nielen Marais (1871-1936). In dit artikel wil ik de wordingsgeschiedenis van het begrip hesperiaanse melancholie uit de doeken doen: een geschiedenis die ons naar verschillende taalgebieden en naar het snijvlak van wetenschap, literatuur en persoonlijke biografie zal voeren.

\section{Marais}

Weinig mensen konden meer geschikt zijn om de geestelijk vader te worden van een zwaarmoedig begrip als hesperiaanse melancholie dan Eugène Nielen Marais. Marais' leven kan omschreven worden als een opeenstapeling van tragiek. Geboren in Pretoria als jongste kind in een groot gezin van gegoede Afrikaners lijkt het lot hem aanvankelijk goedgezind: hij ontvangt een gedegen scholing en maakt een bliksemcarrière als journalist bij de Pretoriaanse krant Land en Volk. In 1894 trouwt hij bovendien met Aletta Beyers, naar zijn eigen zeggen "just about the most perfect female in body and mind that God ever planted in South Africa" (Rousseau 1974: 71).

Aletta sterft echter al het jaar daarop in het kraambed. Haar dood schokt Marais diep. Sommige biografen zien in deze gebeurtenis de "eerste oorsaak" van de plaag die het leven van Marais steeds meer zal laten ontsporen: zijn toenemende morfinegebruik, dat hem "tydelike uitkoms uit sy sielesmart en die gevoel van doelloosheid van sy bestaan" geboden zou hebben (Du Toit 1957: vi). In werkelijkheid was Marais al eerder aan de opiaten verslingerd geraakt. Maar het tragische verlies van zijn vrouw in het kraambed zal zijn afhankelijkheid van 
verdovende middelen niet verminderd hebben, en enkele jaren later begint hij reukwater te gebruiken om de zoetige geur van morfine te maskeren die hem bijna permanent omgeeft (Rousseau 1974: 137).

Om zijn leven op een nieuw spoor te brengen, vertrekt Marais in 1897 naar Londen, waar hij aanvankelijk medicijnen en later rechten studeert. Ook op deze onderneming rust echter geen zegen. Twee jaar later breekt de Boerenoorlog uit tussen het Verenigd Koninkrijk en Transvaal. Als onderdaan van een vijandige natie wordt de bewegingsvrijheid van Marais beperkt. Tegen het eind van de oorlog weet hij zich desondanks aan te sluiten bij een Duitse hulpexpeditie die munitie naar Zuid-Afrika moet brengen. De expeditie strandt in de moerassen van Mozambique, waar Marais en passant malaria opdoet. Aan de oorlogshandelingen kan hij verder geen bijdrage meer leveren, en onmachtig moet hij toezien hoe de Boerenrepublieken zich onder de Engelse overmacht moeten buigen.

Zijn latere faam zal Marais niet ontlenen aan deze tamelijk roemloze oorlogsavonturen, maar aan zijn activiteiten op twee andere gebieden: dat van de letteren en dat van de ethologie, de wetenschappelijke bestudering van het gedrag van dieren. Over beide werkterreinen zou de Boerenoorlog een beslissende schaduw blijven werpen. Het meest direct zou dat het geval zijn op het gebied van de literatuur. Hoewel Marais was opgegroeid in een overwegend Engelstalig huishouden en hij zich voor zijn gedichten en persoonlijke correspondentie tot die tijd vrijwel uitsluitend van het Engels had bediend, besloot hij na de Boerenoorlog expliciet om zich voortaan in het Afrikaans te gaan uitdrukken. Vandaag geldt hij als één van de meest vermaarde vertegenwoordigers van de Tweede Afrikaanse Taalbeweging die een belangrijke bijdrage leverde aan de volwassenwording van het Afrikaans als literaire taal. Zijn gedicht "Winternag," dat in juli 1905 verscheen in Land en Volk, werd omschreven als een "evenement" en wordt ook tegenwoordig nog vaak beschouwd als "die eerste letterkundig betekenisvolle Afrikaans gedig" (Kritzinger 1957: ix; z.a z.d.).

"Winternag"

$\mathrm{O}$ koud is die windjie

en skraal,

En blink in die dof-lig

en kaal,

so wyd as die Heer se genade,

lê die velde in sterlig en skade.

En hoog in die rande, 
versprei in die brande, is die grassaad aan roere soos winkende hande.

O treurig die wysie

op die ooswind se maat, soos die lied van 'n meisie in haar liefde verlaat. In elk' grashalm se vou

blink 'n druppel van dou, en vinnig verbleek dit

tot ryp in die kou! (Marais 1957: 9) ${ }^{1}$

Met zijn neoromantische toon van Weltschmerz verwoord in heldere, bewust eenvoudige taal kan het gedicht als representatief gelden voor een groot deel van Marais' poëtische oeuvre, dat overigens vrij bescheiden van omvang zou blijven.

\section{Doornhoek}

Zijn literaire werk zou Marais tot een icoon van het Afrikaans zelfbewustzijn maken (Reybrouck 2001: 222-223; Swart 2004b). Zijn internationale roem - zij het voornamelijk postuum - dankt hij echter aan zijn ethologische arbeid. Als Marais na de Tweede Boerenoorlog terugkeert naar Zuid-Afrika, ontvlucht hij al snel zijn geboortestad Pretoria in de hoop zijn toenemende afhankelijkheid van morfine en een mislukte liefde te boven te komen (Swart 2004a: 242). In 1907 doet hij zijn krant Land en Volk van de hand. Van de opbrengst bouwt hij een huis in de wildernis bij Waterberg, in het uiterste noordwesten van Transvaal, dicht bij de grens van wat nu Botswana is. Het onderkomen ligt zeer eenzaam, aan het eind van een moeilijk begaanbare kloof. Aan de tijd die Marais op deze afgelegen plek doorbrengt zou hij later met nostalgie terugdenken: "ek denk nie dat ek ooit in my lewe 'n gelukkiger tydperk deurleef het nie as die drie jaar wat ons in die gebergte van Doornhoek deurgebring het nie" (Marais 1938: 23). In het woeste landschap van wilde vijgenbomen, boomvarens en bergstroompjes hoopt Marais naar eigen zeggen ertsen te vinden, maar lijkt hij zich in de praktijk vooral aan natuurstudie gewijd te hebben, waarbij hij onder andere gifslangen en termieten intensief observeert.

\footnotetext{
${ }^{1}$ Christopher Heywood (Heywood 2004: 43) vermeldt, m.i. ten onrechte, dat dit gedicht de stemming
} van hesperiaanse melancholie beschrijft. 
Het is zijn studie van laatstgenoemde insectensoort die voor nieuwe dramatische verwikkelingen in zijn leven zal zorgen. De aantekeningen die Marais bijhoudt van zijn observaties op Doornhoek, werkt hij uit in een aantal artikelen in het Afrikaans die van december 1925 tot januari 1926 in het ZuidAfrikaanse gezinsblad Die Huisgenoot verschijnen. Hij poneert hierin de these dat een termietennest niet als een verzameling individuele termieten moet worden gezien, maar als één organisme, waarbij de afzonderlijke termieten beschouwd kunnen worden als de organen van een lichaam of de rode en witte bloedlichaampjes in de bloedbaan. Eind 1926 publiceert Maurice Maeterlinck, vermaard symbolist en enige Belgische winnaar van de Nobelprijs voor literatuur, een boek getiteld La vie des termites, waarin precies dezelfde theorie over de termietensamenleving gepresenteerd wordt. Wanneer Marais hierop gewezen wordt, oppert hij onmiddellijk de mogelijkheid van plagiaat. De welgestelde, internationaal gerenommeerde schrijver zou misbruik gemaakt hebben van Marais' marginale positie als in het Afrikaans publicerende en niet academisch erkende onderzoeker om met zijn bevindingen aan de haal te gaan. Gesteund door een lobby van nationalistische Boeren overweegt Marais om Maeterlinck voor de rechter te dagen, maar de hoge kosten die hiermee gemoeid zijn en bijkomende logistieke moeilijkheden (Europa is ver weg) weerhouden hem hier uiteindelijk van.

Of Maeterlinck Marais werkelijk geplagieerd heeft, is nog steeds een niet geheel opgehelderde kwestie (Reybrouck 2001: 85). Het concept van de insectensamenleving als organisme, zo is door meerdere auteurs reeds opgemerkt, was al in 1911 naar voren gebracht door W.M. Wheeler in een artikel in het vakblad Journal of Morphology met de alleszeggende titel "The ant colony as an organism" (Reybrouck 2001: 85, 132; Rousseau 1974: 399). Wheeler's ideeën waren echter veel schetsmatiger dan die van Marais en Maeterlinck, en het is onwaarschijnlijk dat één van beide auteurs met zijn artikel bekend was. Maeterlinck daarentegen kon zeker wel met Marais' werk in aanraking zijn gekomen. De culturele banden tussen Zuid-Afrika en het Nederlandse taalgebied waren in die tijd veel steviger dan tegenwoordig, en Die Huisgenoot werd ook in Nederland en Vlaanderen gelezen. Maeterlinck, zelf weliswaar francofoon, had genoeg vrienden die de culturele ontwikkelingen in Zuid-Afrika op de voet volgden en die hem op het artikel van Marais hadden kunnen wijzen (Reybrouck 2001: 178). De mogelijkheid van plagiaat is dus meer dan alleen theoretisch. Leon Rousseau, Marais' meest gezaghebbende biograaf, geeft een 'open verdict' in de zaak (Rousseau 1974: 399). David Reybrouck, die in 2001 een literair verslag publiceerde van zijn onderzoek naar deze kwestie, houdt het voor waarschijnlijk dat Maeterlinck inderdaad leentjebuur heeft gespeeld bij de Zuid-Afrikaanse 
natuurvorser. Marais zelf had al gewezen op een miniem maar veelbetekenend detail: het woordje nasicorne dat hij als eerste had gebruikt om een bepaald type termiet te beschrijven en dat door Maeterlinck klakkeloos was overgenomen, blijkbaar in de veronderstelling dat het een algemeen gangbare term betrof. Ook Reybrouck concludeert, met name op basis van dit minuscule spoor, dat Maeterlinck wel degelijk door Marais geïnspireerd is geweest (Reybrouck 2001: $109,132-133,172-173){ }^{2}$

\section{Bobbejane}

Terug naar hesperiaanse melancholie. De inspiratie om zich met dit verschijnsel bezig te houden doet Marais niet op bij termieten, maar bij een andere diersoort die hij op de Doornhoek bestudeert: bavianen. In de omgeving van zijn hut treft hij in 1907 een groep van zo'n driehonderd van deze apen aan. Door het recente oorlogsgeweld en de meedogenloze antiguerrillatactieken van de Britten is het gebied rond de Waterberg ontvolkt geraakt, en de bavianen, waar al jaren niet op is geschoten, hebben hun angst voor de mens grotendeels verloren. Marais lokt de dieren door maïs te strooien, en weldra zijn ze zo aan hem gewend, rapporteert hij in Burgers van de Bergen, dat hij als een herder tussen de schapen ongestoord tussen hen door kan lopen. De Mauser-revolver die hij als bescherming draagt, hoeft hij niet één keer te gebruiken (Marais 1973: 20). In deze ideale omstandigheden observeert Marais drie jaar lang het gedrag van de troep bavianen. Daarmee is hij de eerste die op een dergelijke systematische manier apen in het wild bestudeert (Morris 2009: 238-240; Reybrouck 2001: 8-9). Als de omgeving langzamerhand weer dichter bevolkt raakt, begint de troep bavianen opnieuw angst voor mensen te ontwikkelen, en "na 'n broederskap van drie jaar" breekt Marais zijn onderzoekingen in Doornhoek af (Marais 1973: 20).

In 1916, zeven jaar later, begint Marais zijn waarnemingen uit te werken tot een Engelstalig geschrift dat hij de titel The Soul of the Ape meegeeft. Hierin beschrijft hij waarschijnlijk voor het eerst het fenomeen "hesperian depression" [sic]. Allereerst bespreekt hij het voorkomen ervan bij de mens. Het is niet "in great cities and in the midst of strenuous cicilizations" dat deze getijdenbeweging van

\footnotetext{
${ }^{2}$ Paradoxaal genoeg bracht het plagiaatschandaal Marais korte tijd een modicum van internationale aandacht. Zijn artikelen over de termiet worden in 1934 gebundeld als Die Siel van die Mier; een Engelse vertaling verschijnt in 1938, kort daarna gevolgd door een Franse en een Duitse: zie Eug. N. Marais, The Soul of The White Ant (London: Methuen 1938) en Eugène Nielen Marais, Moeurs et coutumes des termites. Étude de la fourmi blanche de l'Afrique du Sud (Paris : Payot 1938). Een Nederlandse editie van het boek, onder de titel De wonderwereld van de termietenstaat, zou pas in 1958 verschijnen bij Uitgeverij De Haan te Zeist. Maeterlinck lijkt trouwens nog aanzienlijk beter geboerd te hebben met zijn termieten (aldus Reybrouck 2001: 188).
} 
de ziel het beste kan worden waargenomen, maar onder "natural conditions" bijvoorbeeld in het Zuid-Afrikaanse velt, waar het zowel onder Europeanen als inheemsen een algemeen bekend verschijnsel is (Marais 1973: 102-103).

Among the natives these phases are very noticeably translated into behaviour. An air of quietness and dejection falls upon the village just about sunset. The men and women go listlessly and mournfully about such tasks as still remain to be done. The old people gather in sheltered corners or about the fireplaces, quite silent. Conversation ceases. No song is heard and no sound of musical instruments. It seems very much like the dejection of utter physical weakness. The little children are by no means exempt. All laughter ceases, the games come to an end and there is a general tendency to creep closer to the mothers and elders; an apparent craving for protective fondling and endearments. As the night falls, the scene changes. The fires are newly made. Conversation and laughter are heard once more. Songs and the sound of music arise and under the brightening stars the young people congregate at the dancing-place, where the last vestiges of dejection and weariness vanish. (Marais 1973: 102-103) ${ }^{3}$

Bij de bavianen die hij observeerde, schrijft Marais, kan hetzelfde gedrag worden waargenomen. Even voor zonsondergang waren de apen nog volop actief: er werd geroepen, gespeeld, gepaard.

With the setting of the sun and the first deepening of the shadows a singular transformation came over the entire scene. Silence fell upon them gradually. The 'talking' ceased. The little ones crept cuddlingly into the protecting arms of their mothers. The romping young folk joined different groups, generally on the higher flat rocks from which a view could be had of the western horizon. The older ones assumed attitudes of profound dejection, and for long intervals the silence would be unbroken except for the short whimpering complaints of the little ones and the consoling gurgling of the mothers. And then from all sides would come the sound of mourning, a sound never uttered otherwise than on occasions of great sorrow - of death and parting. (Marais 1973: 105-106)

Ook bij de bavianen verdween deze "evening melancholy" zodra het volledig donker was geworden. "When the troop finally moved on to the krans or to the entrance of the sleeping-cave, the games were resumed and sometimes on moonlight nights continued for several hours" (Marais 1973: 106).

\footnotetext{
3 "All these signs are, of course, absent in a village where beer has been made and being drunk," merkt Marais in een voetnoot bij deze passage op.
} 
Marais voltooit het manuscript van The Soul of the Ape in 1919 en stuurt het naar zijn zoon Eugène jr. in London, die het moet uitschrijven en overtypen met de uiteindelijke bedoeling het naar het Smithsonian Institute in Washington te sturen. Dit laatste lijkt inderdaad ook gebeurd te zijn, maar van publicatie komt blijkbaar niets (University of Johannesburg Library and Information Centre 1995). ${ }^{4}$ Wel verschijnt in oktober 1926 een zeer verkorte samenvatting van het boek als artikel in het tijdschrift Psyche, met daarin ook een korte beschrijving van de "gloom of twilight" bij mens en dier (Marais 1926a). In dezelfde periode werkt Marais het Engelstalige manuscript om tot een serie Afrikaanstalige artikelen voor Die Huisgenoot, als vervolg op zijn succesvolle reeks over termieten. Op 13 mei 1927 verschijnt in deze serie eveneens een bijdrage over "hesperiese neerslagtigheid." Deze artikelen bieden de meest volledige weerslag van Marais' ideeën over de psyche van de aap in het algemeen en hesperiaanse melancholie in het bijzonder. Ik zal ze daarom op de volgende bladzijden uitgebreid bespreken.

\section{Donkere plekken van de ziel}

Net als in The Soul of the Ape wordt Marais' uiteenzetting over hesperiaanse melancholie in Die Huisgenoot voorafgegaan door een lange verhandeling over wat hij in het Afrikaans "euforiese vergiftiging" noemt. Deze lange verhandeling, die twee complete artikelen beslaat, doet op z'n zachtst gezegd vreemd aan in een gezinsblad zoals Die Huisgenoot voorgaf te zijn. Marais opent het stuk met een uitgebreide catalogus van de roesmiddelen die de mensheid ten dienste staan: alcohol, opium, cannabis sativa, coca, nicotine - een lijst waaraan hij met nauw verholen plezier ook koffie en thee toevoegt: "Altwee is euforiese middels, waarvan die invloed op die menslike gestel afhanklik is van die giftige werking van'n dodelike alkaloïde" (Marais 1926b; Marais 1965: 20). Hoewel onopzettelijke dronkenschap in de natuur bij veel hogere diersoorten en mogelijk zelfs insecten voorkomt, is "vrywillige euforiese vergiftiging," zo meent Marais, voorbehouden aan de mens en de 'hogere apensoorten' (waartoe hij ook de bavianen rekent). Hiervoor geeft hij twee oorzaken. Ten eerste onderscheiden zowel de mens als de aap zich van 'lagere' zoogdieren doordat hun instinctieve "erflike omgewingsgeheue" (wij zouden zeggen: instinct) relatief zwak ontwikkeld is en hun "individuele oorsaaklike geheue" relatief sterk. Waar een jonge otter die ver van water in gevangenschap is grootgebracht meteen in een rivier zal springen om vis te vangen als hij de kans krijgt, is een in soortgelijke omstandigheden

\footnotetext{
${ }^{4}$ Marais had in 1914 reeds een bijdrage getiteld "Note on some effects of extreme drought in Waterberg, South Africa" in het Smithsonian Report gepubliceerd.
} 
opgegroeide baviaan volstrekt hulpeloos als hij teruggezet wordt in het wild. De aap is daarentegen wel in staat om zich nieuwe informatie eigen te maken die nog niet tot zijn overgeërfde kennispakket behoort. Met andere woorden: mens en aap kunnen leren. Daardoor kunnen ze ontdekken welke planten of vruchten onder welke omstandigheden euforie teweegbrengen, hun bevindingen onthouden, en later tot hetzelfde middel terugkeren om doelbewust opnieuw dit gevoel op te roepen.

Dit verklaart echter nog niet, geeft ook Marais meteen toe, waar bij baviaan en mens dan de sterke neiging vandaan komt om steeds weer deze 'euforiese vergiftiging' op te zoeken. Dat heeft te maken, poneert de natuuronderzoeker, met de tweede karakteristiek die aap en mens gemeen hebben en die rechtstreeks uit de eerste volgt, namelijk bewustzijn:

In korte bewoording sou ek dit so beskrywe: Lewe beteken altyd strewe. Die eerste groei van organiese lewe is 'n stryd teen die swaartekrag van die aarde. Die psige van alle organismes is so ingerig dat dit die lewestryd vernaamlik as pyn en lyding moet gewaar word. [...] die siel van erflike geheue is, so te sê, in 'n groot getal afgeskorte vakkies verdeel. Die druk en pynlikheid van die bestaanstryd is oor ' $n$ wye oppervlakte versprei. In die siel van onerflike geheue val al die pynlikheid van die bestaanstryd op 'n enkel punt wat ons 'bewustheid' noem; en daarom word die mens en die bobbejan 'bewustheid' gewaar as iets gegrondves op pyn en lyding. [...] Vandat die mens geleer het om sy gedagtes in skrif weer te gee, het hy sy eie sielsverdriet bejammer en na middels gesoek; en die vernaamste en tegelyk gunstigste van die middels, in alle stadiums van sy beskawing, is ongetwyfeld die bonatuurlike godsdiens gewees; daarna kom euforiese vergiftiging. (Marais 1965: 29, 30)

Aap en mens betalen dus beide de prijs van hun hogere ontwikkeling in de vorm van een "inherente psigologiese pynlikheid" en om deze pijn te lenigen, nemen ze hun toevlucht tot roesmiddelen. Dit gegeven brengt Marais, net als eerder in The Soul of the Ape, op het punt van de hesperiaanse melancholie, een verschijnsel dat hij presenteert als bewijs par excellence "dat die bobbejaan aan diezelfde pessimisme as die mens onderhewig is" (Marais 1965:31). Zijn beschrijving hiervan wijkt op zich weinig af van die in het eerdere Engelse manuscript. Eén op de tien mensen, heeft een steekproef in zijn omgeving geleerd, lijdt aan deze vorm van neerslachtigheid; en evenals in The Soul of the Ape illustreren uitgebreide citaten uit de wereldliteratuur (Heine, Milton, Gray) de alomtegenwoordigheid van het verschijnsel in de menselijke cultuurgeschiedenis. Het gedrag van de bavianen wordt eveneens in grofweg dezelfde lijnen beschreven - de bedruktheid die zich 
meester maakt van de groep bij zonsondergang en de "weeklag" die daarop volgt. "Daar is waarskynlik in ons hele natuur geen geluid meer hartroerend treurig nie" (Marais 1927; Marais 1965: 36).

Nieuw is het feit dat Marais nu ook met een verklaring voor deze avondlijke melancholie komt. De toestand is kenmerkend, schrijft hij, voor "tropdiere wat in bosse lewe." Ook bij bosbokken bijvoorbeeld is te zien hoe de dieren in de avondschemer stil worden en "in 'n digte klomp bymekaar trek" (Marais 1965: 32). Voor de antiloop heeft dit gedrag een duidelijke functie. De schemering is het moment dat de bedreiging van dagroofdieren het grootst is. In het donker van de nacht verscherpen de zintuigen van de bosbok zich weer, aldus Marais, zodat natuurlijke vijanden minder snel een kans krijgen. De "bedeesde waakzaamheid" rond de schemertijd dient dus een duidelijk biologisch doel.

Iets dergelijks geldt ook voor de baviaan. De schemering is de tijd waarop de luipaard, zijn grootste natuurlijke vijand, doorgaans toeslaat. "Sy moment van grootste gevaar is net wanneer hy, teen die einde van die dag, moeg en afgemat, op weg is na die slaapplek. Eens op die slaapplek, almal dig bymekaar - daar is hy veilig" (Marais 1965: 39). Hesperiaanse melancholie is hierbij dus het mechanisme waarmee de natuur hem "deur psigologiese inwerking" tracht te beveiligen. Het dient niet verward te worden met angst voor het donker, al heeft dit een niet geheel ongelijksoortige functie: het houdt de troep gedurende de nacht op de slaapplek bij elkaar en voorkomt "afdwalinge" (Marais 1965: 39).

Bij de mens is deze hesperiaanse tristesse - en trouwens ook de angst voor het donker - als erfenis van de evolutie achtergebleven, net als bijvoorbeeld de anatomische aanzet tot staartgroei. Voor de moderne mens heeft deze gemoedstoestand echter geen enkel nut meer, maar woekert zij slechts voort "in die donker plekke van sy siel," als een "verskriklike psigologiese spook" (Marais 1965: 39). Het is daarom niet verwonderlijk dat het verschijnsel zich met name manifesteert bij kinderen en bij 'primitieve' volkeren, die volgens Marais op een lagere trede van de evolutionaire ontwikkelingsladder staan. Dat geldt overigens ook voor euforische vergiftiging: behalve de bavianen is er niemand zo onmatig in het gebruik hiervan als de "Boesman" (San), die Marais als een tussenstap tussen mens en dier beschouwt. "Daar was geen vergroting in die bewering wat dikwels gemaak is, dat elke Hottentot en elke Boesman 'n gebore dronkaard was, en dat daar slegs twee perke aan hulle onlesbare dors waarneembaar was: die hoeveelheid brandewyn en die dood" (Marais 1965: 14). Hoe hoger op de trap van ontwikkeling en beschaving, hoe groter de controle van de mens over deze neiging, al is het voornamelijk, schrijft Marais niet zonder ironie, door de "vermeerderde en verhoogde afleidings" die de moderne civilisatie met zich meebrengt (Marais 1965: 12). 


\section{5. “Nuttelose aaplike gemoedstoestande"}

Ondertussen roept Marais' verklaring van hesperiese neerslagtigheid een tegenspraak op die hij zelf niet opgemerkt lijkt te hebben. In The Soul of the Ape zowel als De siel van de aap dient het voorkomen van hesperiaanse melancholie immers als bewijs dat ook 'hogere' apen dezelfde gemoedstoestand kunnen vertonen als de mens in enkele van de mooiste gedichten uit de wereldliteratuur heeft verwoord. "Here, too," had Marais geschreven, "one has to deal with a mental state apparantly characteristic of man alone, and quiet evidently an attribute of his consciousness" (Marais 1973: 101). Nu lijkt het er echter op dat niet de aap in dit opzicht op de mens lijkt, maar eerder de mens op de aap, en dat beide een ingeprente emotionele reflex vertonen die ze ook met 'lagere' zoogdieren als de bosbok gemeen hebben. Of ontleent de baviaan zijn aparte status aan het feit dat hij zijn hesperiaanse smart bewust ervaart en uit, zoals de mens dat bijvoorbeeld in poëzie heeft gedaan? Nergens maakt Marais expliciet of hij denkt dat ook bijvoorbeeld bosbokken daadwerkelijk hesperiaanse melancholie ondergaan of dat ze slechts een instinctieve reactie vertonen waarbij "pyn en lydng" over de vele "vakjes" van hun overgeërfd omgevingsgeheugen zijn uitgesmeerd.

Voor Marais, zo lijkt het, is deze vraag van ondergeschikt belang. Wie The Soul of the Ape of zijn Afrikaanse baviaanartikelen leest, krijgt al snel in de gaten dat het hem niet in de eerste plaats te doen is om de aap op zich, en nog veel minder om de bosbok. Zijn werkelijke interesse betreft de werking en het ontstaan van de menselijke geest. De 'aap' in De siel van de aap is dan ook de mens. Tientallen jaren voordat de Britse bioloog Desmond Morris deze zienswijze zou populariseren, zoekt Marais de verklaring voor ons gedrag al in onze evolutiegeschiedenis, waarbij hij een continuüm veronderstelt tussen mens en dier, met de verschillende mensenrassen als kleinere tussenstappen. Enerzijds blijken daarbij bepaalde eigenschappen die veelal als uniek menselijk worden beschouwd, zoals bewustzijn, al bij de 'hogere' apen te kunnen worden aangetroffen. Anderzijds zijn sommige op het eerste gezicht zeer menselijke gedragingen, zoals hesperiaanse melancholie, terug te voeren op atavistische relicten uit ons 'wilde' verleden als aap of bosdier.

Een aantal auteurs heeft zich afgevraagd of er niet ook meer persoonlijke motieven meespelen in de manier waarop Marais over apen schrijft (Morris 2009: 239-240). Wie de bavianenartikelen uit Die Huisgenoot doorneemt, kan zich inderdaad moeilijk aan deze indruk onttrekken. Met name de twee bijdragen over "euforiese vergiftiging" lezen als een persoonlijke Auseinandersetzung van Marais met zijn morfineverslaving. Een zekere dubbelslachtigheid wordt daarbij in zijn houding zichtbaar. Enerzijds stelt hij enigszins provocatief dat de 
neiging tot het gebruik van "euforische middels" (Marais 2006, I: 214) praktisch universeel verbreid is onder de 'hogere' aapachtigen en de verschillende rassen en volken van de mensheid. Deze neiging is een rechtstreeks gevolg van de meest eminente verworvenheid van de hoogst ontwikkelde primaten, namelijk het bewustzijn. Het lijkt me evident dat Marais hier op zoek is naar de 'wortel' van zijn eigen morfinisme. Anderzijds zijn beide teksten niet simpelweg een apologie van drugsgebruik. Er is bij mensen immers ook "inhibisie" (Marais 2006, I: 216) mogelijk. Sterker nog, hoe hoger het niveau van (evolutionaire) ontwikkeling en beschaving, hoe groter het vermogen om de zucht naar roesmiddelen te beheersen.

Dit roept de vraag op waarom Marais zelf dan juist zo vatbaar blijkt voor drugs. Als dichter, jurist, en autodidactisch veldbioloog kon hij toch zeker voor één van de meest ontwikkelde en beschaafde inwoners van het Zuid-Afrika van zijn tijd gelden? Onder de oppervlakte van zijn tekst, zo lijkt het, is Marais op zoek naar een antwoord op deze vraag. En het is misschien precies in zijn uiteenzetting over hesperiaanse melancholie dat hij de eerste lijnen hiervan schetst. Als met bewustzijn begiftigd primaat is de mens immers niet alleen onderhevig aan een versterkte gewaarwording van de "pyn en lyding" van het bestaan; hij kampt ook nog met "nuttelose aaplike gemoedstoestande" als hesperiaanse melancholie (Marais 1965: 39). Net zoals er nu en dan nog steeds mensen met een staart geboren worden, zo zijn er ook individuen, lijkt Marais te suggereren, die in verhevigde mate aan hesperiaanse neerslachtigheid lijden: zozeer zelfs dat er van een "patologiese toestand" gesproken kan worden (Marais 1965: 36, 32). Het stuk over hesperiaanse melancholie eindigt met een omineuze vooruitverwijzing naar "watter verskriklike rol die gevoelstelsel, wat neerslagtigheid as 'n psigologiese moment veroorsaak, in die menslike siel speel wanneer dit patologies optree" (Marais 1965: 40).

Is het te ver gezocht om te veronderstellen dat Marais hier over zichzelf spreekt? Formuleringen als "verskriklike psigologiese spook" en "nuttelose bron van lyding" klinken nogal heftig in de oren voor een gemoedsaandoening die in wezen vrij poëtisch aandoet (Marais 1965: 39). Spreekt Marais hier wellicht over zijn eigen depressies, die de diepere oorzaak zouden kunnen hebben gevormd voor het feit dat hij zo'n zucht naar opium ervoer? Beschrijft hij zichzelf hier impliciet als een soort man met de staart - iemand die door de duistere werking van de wetten van de erfelijkheid met een meer dan gemiddelde portie aapachtige, al dan niet hesperiaanse, neerslachtigheid is opgescheept? Het valt vanzelfsprekend niet met zekerheid te zeggen, maar het heeft er alle schijn van dat Marais met zijn overdenkingen over hesperiaanse zwaarmoedigheid niet in de laatste plaats ook meer licht wilde laten schijnen op de donkere plekken van zijn eigen ziel. 


\section{Gouden appels}

Op de benaming hesperiaanse melancholie zelf ben ik tot nu toe niet dieper ingegaan. Ook Marais doet dit niet. In zijn teksten vermeldt hij nergens expliciet dat hij deze term zelf bedacht heeft en laat hij zich evenmin uit over de precieze betekenis of etymologie ervan. Op het meest basale niveau is deze overigens vrij eenvoudig. Hesperus is een oude naam voor Venus, de Avondster, en hesperiaans staat dus gewoon voor avondlijk. Maar het woord draagt ook mythologische connotaties. Het kan verwijzen naar de Hesperiden, de dochters van Atlas die in hun tuinen de wacht houden over de gouden appels van de eeuwige jeugd en daarvan volgens de mythe door Hercules met list en bedrog werden bestolen. Marais zal zich van deze connotaties zeker bewust zijn geweest. Had hij hiermee iets op het oog? Het is verleidelijk om ook in zijn naamkeuze een subtekst over zijn drugsgebruik te lezen. De gouden appels van de eeuwige jeugd die door Hercules werden gestolen staan dan voor de verdovende middelen die als enige verlichting kunnen geven van (overgeërfde) hesperiaanse melancholie. Is dat te vergezocht bij iemand die in zijn ex libris een slang voerde die symbool stond voor morfine, met als onderschrift "Dit of Doodt" (Rousseau 1974: 125)? En die zonder tegenspraak de Engelse schrijver De Quincey citeert wanneer deze de opium omschrijft als "'n gebenedyde Wese met de sleutels van die Paradys" (Marais 1965: 30)?

Een meer algemene interpretatie is echter ook denkbaar. De tuinen van de Hesperiden staan dan voor de gelukzalige onwetendheid van het voorbewuste bestaan van 'lagere' organismen. Dit 'paradijs' is volgens Marais voorgoed voor ons verloren gegaan toen bij de hogere primaten bewustzijn ontstond en daarmee ook het besef optrad dat het bestaan uit lijden en strijd bestaat. Ook de beleving van hesperiaanse melancholie was voor Marais, in ieder geval in eerste instantie, een gevolg van het ontstaan van bewustzijn, en daarmee een vorm van pijn die indirect een nasleep vormt van de 'verdrijving' uit de 'tuinen van de Hesperiden' van het voorbewuste. Marais doet echter opnieuw geen expliciete uitspraken die wat dit betreft een tipje van de sluier oplichten.

\section{Nasleep}

De artikelen in Die Huisgenoot zullen de laatste zijn waarin Marais over hesperiaanse melancholie rept. In 1932 zou de dichter nog een aantal artikelen over bavianen publiceren in Ons Vaderland die na zijn dood werden gebundeld als Burgers van die Berge. In deze bijdragen komt echter noch de lokroep van de 
kunstmatige euforie noch de somberte van het avonduur ter sprake. ${ }^{5}$ In 1935 komt Marais in contact met de in Engeland wonende Zuid-Afrikaan Winifred de Kok, die zich bereid verklaart om werk van hem in het Engels te vertalen. Marais stelt Die siel van die aap voor - blijkbaar is hij het bestaan van The Soul of the Ape vergeten of beschouwt hij het manuscript als verloren of verouderd. De keuze valt uiteindelijk echter op Die Siel van die Mier. Het werk over bavianen is volgens Marais te zeer verbrokkeld. "I just can't get up sufficient enthusiasm to arrange this particular material in an Afrikaans book," schrijft hij aan zijn vertaler (Rousseau 1974: 494).

Lichamelijk is Marais dan al een wrak. De oorzaak hiervan is wederom de 'euforiese vergiftiging.' De dichter heeft enkele keren geprobeerd om af te kicken van de morfine, maar slaagt daarin niet. Het bemachtigen van opiaten wordt steeds moeilijker nu deze internationaal op de lijst van verboden middelen zijn gezet. De laatste jaren van zijn leven probeert hij het hoofd boven water te houden als krantenstukjesschrijver en halve kwakzalver, en door semipermanent als logeergast bij vrienden en familie te verblijven.

In de herfst van 1936 bevindt Marais zich zo op de boerderij van zijn vriend en mecenas Gustav Preller. Zijn morfinevoorraad is uitgeput en hij heeft geen aanvulling weten te vinden. Rillend en rokend ligt hij op bed. Buiten regent het. Hij weet wat er nu gaat komen. In zijn artikel in Die Huisgenoot van tien jaar terug had hij de "abstinens-simptome" van opiaten al in klare taal beschreven: "Onthouding veroorsaak simptome baie gevaarliker as die chroniese vergiftiging self, en eindig dikwels in die dood. In dié opsig is opium alleenstaande, en ook, derhalwe, die gevaarlikste onder die gifsoorte deur die mens eufories gebesig" (Marais 1965: 19). ${ }^{6}$

Aan het slot van hetzelfde artikel had Marais tevens met klaarblijkelijke instemming de slotsom van de Oud-Egyptische Tweespraak tussen de schrijver en diens ziel geciteerd: het enige volmaakte middel om aan de inherente pijn van het leven te ontkomen, was "om self 'n einde aan die bestaan te maak" (Marais 1965: 30). Hij staat op van zijn bed en vraagt aan zijn gastheer een geweer: om een slang te doden die hij op het erf gezien heeft, zo beweert hij. Het wapen wordt hem geweigerd, er zouden geen patronen meer zijn. Daarop loopt hij naar

\footnotetext{
${ }^{5}$ Delen van The Soul of the Ape waren al in 1920 door Marais in het Afrikaans vertaald en van september 1920 tot mei 1921 gepubliceerd in Die Banier, een bijlage bij het Afrikaner tijdschrift Die Brandwag. Marais' verhandeling over hesperiaanse melancholie maakt hier echter geen deel van uit. De vier artikelen uit Die Banier werden in 1928 met een aantal andere stukken gebundeld onder de titel Natuurkundige en wetenskaplike studies; de tekst hiervan is ook te vinden in Marais' Versamelde werke (Marais 2006: 1:173-187; vergelijk Marais 2001: 139-140).

${ }^{6}$ Marais had de verschijnselen van cold turkey eerder al aan den lijve ondervonden, onder andere tijdens een jachtpartij in het velt waarbij hij door zijn morfinevoorraad was geraakt (Rousseau 1974: 226).
} 
de boerderij van de buren en herhaalt daar zijn verzoek. De buurman geeft hem een dubbelloops jachtgeweer. Bij een boom even verderop zet Marais het wapen tegen zijn borst en probeert zich door het hart te schieten. Als dit mislukt, neemt hij de loop in zijn mond en haalt nogmaals over. De datum is 29 maart 1936: vanzelfsprekend is het in de avond, rond het schemeruur (Rousseau 1974: 513514; Reybrouck 2001: 164).

Na Marais' zelfverkozen dood komt zijn canonisatie als Afrikaanse cultuurheld pas goed op gang (Swart 2004b). Aan zijn overpeinzingen over hesperiaanse melancholie wordt daarbij weinig aandacht besteed. Ook tijdens Marais' leven lijken zijn hypothesen dienaangaande grotendeels onopgemerkt te zijn gebleven. De enige mij bekende verwijzing komt uit het nogal obscure werkje The History of the Devil: The Horned God of the West van de al even obscure Robert Lowe Thompson, B.A., dat werd uitgegeven door Kegan Paul te London in 1929. De bevindingen van 'E.P. Marais' betreffende de Abendschmerz van bavianen worden in deze pseudowetenschappelijke publicatie terloops aangehaald. De bron van de schrijver was daarbij zonder twijfel Marais' artikel over "Baboons, Hypnosis, and Insanity" uit 1926 (Thompson 1929: 22). Een bespreking van Thompsons boek in de Virginia Quarterly Review maakt ook terloops melding van 'Hesperian depression' (Porterfield 1929).

Aan deze vrijwel volledige radiostilte rond de hesperiaanse neerslachtigheid komt pas zo'n dertig jaar na Marais' dood een einde. Het feit dat dit gebeurt, is indirect te danken aan één persoon: de scenarist en toneelschrijver Robert Ardrey (1906-1980). In de jaren vijftig had Ardrey zijn studie antropologie weer opgepakt en was hij zich gaan interesseren voor de evolutiegeschiedenis van de mens. In dat kader was hij ook op de figuur van Marais gestuit. In de jaren zestig begint hij zich met ware zelotenijver voor diens rehabilitatie sterk te maken, zozeer zelfs dat hij zijn boek African Genesis (1961) aan Marais opdraagt, waarbij hij de Zuid-Afrikaan als een soort Van Gogh van de wetenschap bestempelt (Morris in Marais 1973: 7). Het is aan Ardrey te danken dat The Soul of the Ape exact vijftig jaar na zijn voorlopige voltooiing alsnog in boekvorm verschijnt. In tegenstelling tot wat velen meenden, was het manuscript van het werk namelijk geenszins verloren gegaan, maar in handen gebleven van Marais' zoon, die in de decennia na zijn vaders dood vergeefs had getracht er een uitgever voor te vinden.

In 1969 kwam het boek waarvan Marais zoveel had verwacht dan eindelijk toch nog uit, voorafgegaan door een bewierokende inleiding van Ardrey en met inbegrip van de twee paragrafen over hesperiaanse melancholie. De verschijning viel op een gunstig moment: het werk van academici als Konrad Lorenz en populairwetenschappelijke auteurs als Desmond Morris had evolutionaire verklaringen van menselijk gedrag al min of meer gemeengoed 
gemaakt. Hoewel de academische gemeenschap sceptisch bleef en blijft over de wetenschappelijke waarde van Marais' werk, wordt The Soul of the Ape nog steeds met enige regelmaat herdrukt. Sindsdien duikt het begrip hesperiaanse melancholie of hesperiaanse depressie regelmatig in publicaties op, bijvoorbeeld in (populair)wetenschappelijke werken op het gebied van paleoantropologie of evolutiebiologie. Bijna zonder uitzondering wordt daarbij geput uit het algemeen beschikbare The Soul of the Ape, zonder dat er kennis wordt genomen van het rijkere Afrikaanstalige werk. ${ }^{7}$

\section{Plagiaat}

Het meest invloedrijk zou Marais' idee van hesperiaanse melancholie uiteindelijk in de wereld van de populaire psychologie blijken te zijn. Deze invloed is tot nu toe onopgemerkt gebleven. Daar is een zeer specifieke reden voor. In 1971 verschijnt in het gerenommeerde Journal of the American Psycho-Analytical Society een artikel getiteld "On Hesperian Depression." De auteur ervan is William G. Niederland (1904-1993), een Duits-Amerikaans psychoanalyticus die faam had verworven met zijn behandeling van concentratiekampslachtoffers. De derde en vierde zin van dit artikel luiden als volgt:

This brief communication deals with a type of depression which, to my knowledge, has not been described in our literature and, indeed, seems to have escaped close analytic scrutiny, at least as far as its emergence in a specific, distinctly time-related setting is concerned. Because of the predominantly time-of-the-day related occurrence - dusk - I refer to this usually transient, clinically often inconspicuous mood disturbance as Hesperian Depression. (Niederland 1971: 799)

Het stuk vervolgt met een korte uitleg van de mythologische achtergrond van het woord, een drietal gevallen van patiënten die aan de aandoening lijden, en een kleine catalogus van uitingen van hesperiaanse melancholie in kunst, literatuur en religie. Niederland, als overtuigd Freudiaan, verklaart het optreden van

\footnotetext{
${ }^{7}$ Bijvoorbeeld Richard Clark, The Multiple Natural Origins of Religion (Clark 2006), die Marais' waarnemingen met betrekking tot hesperiaanse melancholie recapituleert op p. 166-167. De lacunes die op kunnen treden als Marais' latere uitbouw van zijn theorie buiten beschouwing wordt gelaten, worden duidelijk uit een noot van de auteur op p. 167: “A colleague, Mr. G. Buckley, suggested that at twilight it is less easy to detect predators than in daytime, and that this would account for reduced activity and retreat to safety. However, nocturnal darkness and even moonlight provide no better conditions for seeing than twilight, yet among some primates activity resumes." De eerste hypothese was al door Marais zelf opgeworpen in Die Huisgenoot, waarbij hij tevens Buckley's tegenwerping had besproken. Clark onderschrijft overigens het voorkomen van hesperiaanse melancholie, "a tendency of which I can speak from personal experience."
} 
avondsomberte als een gevolg van "ego states reflecting or reviving earlier ego experiences which once were cathected with libidinal and aggressive energy" en "crepescular experiences" zoals "dusk, nightfall, solitude, sadness, anger, feeling of abandonment, the 'angry' masturbation of the young child in such a setting, and the like" (Niederland 1971: 805, 802). Daarbij refereert hij aan Freuds meer algemene theorie over angst voor het donker als een reflectie van de beklemming die het kind voelt als hij het liefdesobject (dat wil zeggen de moeder of de vader) niet meer kan waarnemen (Niederland 1971: 801). Tot slot suggereert de psychiater nog een meer poëtische verklaring van het verschijnsel, waaraan hij een addendum toevoegt dat zo uit de pen van Marais zou kunnen hebben gevloeid:

It may be that all of us stand enraptured by the view of a beautiful sunset - not only for esthetic but also for defensive reasons, perhaps because the very spectacle of the setting sun, inexorably followed by dusk and darkness, is a reminder of 'the end of the road', as my patient put it. More concretely speaking, Dr. Stanley Weiss, in a personal communication, called my attention to the idea that feelings of depression associated with the waning of the day might have something to do with the custom of the cocktail hour: The drinks, snacks, and get-together may be used, defensively, to counteract depressive feelings and their upsurge at this time of the day. This, of course, would fit into our technologically oriented style of living where care is habitually taken to avoid solitude, meditation, silence and, above all, darkness. (Niederland 1971: 804-805)

Het is mijns inziens evident dat Niederland zijn concept voor Hesperian Depression bij Marais vandaan heeft gehaald. Volgens een voetnoot presenteerde de psychiater de eerste versie van zijn stuk op de 'Fall Meeting' van de American Psychoanalytic Association in december 1970. Dat is meer dan een jaar na de verschijning van The Soul of the Ape, waarin Niederland zeker op de term Hesperian depression gestuit zou zijn, niet alleen in de tekst zelf, maar ook in kleine kapitalen als tussenkop boven twee paragrafen. Als aanhanger van het gedachtegoed van Freud was het des te meer waarschijnlijk dat hij van het boek kennis had genomen, omdat Ardrey het gepubliceerd had als strijdwapen in de discussie tussen Freudianen en evolutiebiologen over wat nu eigenlijk de diepste drijfveer van de menselijke psyche was: Freuds libido of de territoriumdrift en jagersagressie die de mens volgens veel evolutiebiologen van zijn evolutionaire voorouders geërfd zou hebben.

Het is met name in zijn beschrijving van hesperiaanse depressie in de menselijke cultuur dat Niederland zich verraadt. Zijn opsomming van getuigenissen van deze gemoedstoestand in schilderkunst, liturgie en poëzie is 
een spiegeling in meer uitgebreide vorm van de pagina in The Soul of the Ape waarop Marais hetzelfde doet. Niederland kiest (zorgvuldig?) andere voorbeelden - Dante, Shelley, Longfellow, Heine, Wagner - maar de teneur en de globale opbouw is hetzelfde. De gelijkenissen met het een jaar eerder in de boekwinkels verschenen werk van Marais zijn mijns inziens te groot om op toeval te berusten. ${ }^{8}$

Niederlands toe-eigening van andermans idee is blijkbaar nooit door iemand opgemerkt. In Niederlands uitputtende biografie wordt kort zijn bijdrage over Hesperian Depression geparafraseerd, maar over zijn verzwegen inspiratiebron met geen woord gerept (Focke 1992: 289-299). ${ }^{9}$ Zelfs het “In Memoriam" dat na Niederlands dood in 1993 in het vakblad Psychoanalytic Quarterly verschijnt, refereert nog plompverloren aan zijn taalcreativiteit bij het bedenken van dit begrip. "His writing style reflected a certain innate sense of beauty," lezen we in deze necrologie, "For example, in describing a transient, inconspicuous form of depression associated with the oncoming twilight at the close of the day, he chose to call this syndrome 'Hesperian depression,' after Hesperus, the evening star of Greek mythology" (Arlow 1994: 103). De eerste die deze bijzonder poëtische aandoening met "a certain innate sense of beauty" wereldkundig maakte, was echter niet de Duits-Amerikaanse psychoanalyticus Niederland, maar de ZuidAfrikaanse junkiepoëet Eugène Nielen Marais. Meer dan dertig jaar na zijn dood werd deze laatste zo opnieuw, of alsnog, rücksichtslos geplagieerd.

\section{Literatuur}

Arlow, Jacob A. 1994. “William G. Niederland, M.D. 1901-1993.” Psychoanalytic

Quarterly 63: 101-103.

Clark, Richard. 2006. The Multiple Natural Origins of Religion. Bern: Peter Lang.

Heywood, Christopher. 2004. A History of South African Literature. Cambridge:

Cambridge University Press.

Focke, Wenda. 1992. William G. Niederland: Ein Porträt. Psychiater der Verfolgten. Seine Zeit - sein Leben - sein Werk. Würzburg: Köningshausen \& Neumann.

Kritzinger, M.S.B. 1957. "Eugène N. Marais as digter." Versamelde Gedigte. E. Marais.

Pretoria: J.L. van Schaik. viii-xvi.

\footnotetext{
${ }^{8}$ Het kan natuurlijk zijn dat Niederland met zijn opmerking dat hesperiaanse depressie nog niet eerder beschreven is 'in our literature' specifiek doelt op de meer beperkte cirkel van academische of zelfs psychoanalytische literatuur. Marais, in wezen een onderzoeker van het type gentlemanamateur dat in de Victoriaanse tijd niet ongewoon was, was inderdaad altijd buiten het academische circuit blijven staan. Maar een verwijzing door Niederland naar zijn inspiratiebron was ook in dat geval zeker op zijn plaats geweest. Bovendien betoont Niederlands beschrijving en analyse van hesperiaanse melancholie zich bij vergelijkende lezing in mijn ogen niet meer of minder wetenschappelijk dan die van Marais.

${ }^{9}$ Ter verdere illustratie: de psychiater Norman Rosenthal schrijft in Winter Blues (Rosenthal 2013: 116): "Some people report feeling sad at twilight when the sun goes down. One psychoanalyst recognized this symptom and called it 'Hesperian depression,' after the Greek goddess of the dusk, Hesperus."
} 
Marais, Eugène N. 1926a. "Baboons, Hypnosis, and Insanity." Psyche: An Annual General and Linguistic Psychology 7.2 (October): 104-110. 1926b. "Die Siel van die Aap: Euforiese vergiftiging." Die Huisgenoot 3 December 1926: 19-23, 10 December 1926: 15-21. 1927. “Die Siel van die Aap: Hesperiese Neerslagtigheid." Die Huisgenoot 13 Mei

1927: 10-13, 15. 1938. Burgers van die Berge. Pretoria: J.L. van Schaik. 1957. Versamelde Gedigte. Pretoria: J.L. van Schaik. 1965. ' $n$ Paradys van Weleer en ander Geskrifte. Kaapstad \& Pretoria: Human \& Rousseau. 1973. The Soul of the Ape. Hammondsworth: Penguin. 2006. Versamelde werke. Ed. Leon Rousseau. 2 dln. Kaapstad: Human \& Rousseau. <http://www.dbnl.org/tekst/mara002vers01_01/>.

Marais, Johannes Lodewyk. 2001. 'n Ondersoek naar die aard van en opvattings oor Eugène N Marais se wetenskaplike prosa. Proefschrift: Universiteit van Pretoria, 23 Feb. 2013 <http:/ / upetd.up.ac.za/thesis/submitted/etd-02282006-110206/ unrestricted/00front-1.pdf>.

Morris, A.G. 2009. "Zuckerman versus Marais: a primatological collision." South African Journal of Science 105 (May/June): 238-240.

Niederland, William G. 1971. "On Hesperian Depression." Journal of the American Psychoanalytic Association 19: 799-805.

Porterfield, Allen W. 1929. "Up From Savagery." The Virginia Quartely Review: A National Journal of Literature \& Discussion 5.4 (Autumn): 615-620, 23 Feb. 2012 <http://www.vqronline.org/articles/1929/autumn/porterfield-up-savagery>.

Rand, Ayn. 2007. Atlas in Staking. Vert. Jan de Voogt. Krommenie: Boekenmaker.nl.

Reybrouck, David van. 2001. De plaag: Het stille knagen van schrijvers, termieten en ZuidAfrika. Amsterdam: Meulenhoff.

Rosenthal, Norman E. 2013. Winter Blues: Everything You Need to Know to Beat Seasonal Affective Disorder. New York: Guilford Press.

Rousseau, Leon. 1974. Die Groot Verlange: Die Verhaal van Eugène N. Marais. Human \& Rousseau: Kaapstad \& Pretoria.

Swart, Sandra. 2004a. “'Bushveld Magic' and 'Miracle Doctors' - An Exploration of Eugène Marais and C. Louis Leopoldt's Experiences in the Waterberg, South Africa, c. 1906-1917." Journal of African History 45: 237-255.

2004b. "The construction of Eugène Marais as an Afrikaner hero." Journal of Southern African Studies 30.4: 847-867.

Thompson, Robert Lowe. 1929. The History of the Devil: The Horned God of the West. London: Kegan Paul, Trench, Trubner.

Toit, F.G.M. du. 1957. “Eugène Nielen Marais 1872-1936." Versamelde Gedigte. E. Marais. Pretoria, J.L. van Schaik. i-vi.

University of Johannesburg Library and Information Centre B12. 1995. “Eugène N. Marais Collection: Inventory." 23 Feb. 2013 <https://ujdigispace.uj.ac.za/bitstream/ handle/10210/3361/E.\%20N.\%20Marais\%20inventory.pdf?sequence=1>.

z.a. z.d. "Eugène Marais." 9 Jan. 2013 <http://af.wikipedia.org/wiki/Eug\%C3\%A8ne_ Marais>. 